ON the occasion of the international conference on rabies, recently held in Paris, an international society for microbiology was founded, with Professor Jules Bordet of Brussels as president, and Professor Rudolf Krans of Vienna, Drs. Dujarric de la Rivière and Plötz of Paris as secretaries.

THE annual report for 1926 of Earl Haig's British Legion Appeal Fund includes an account of the British Legion Sanatorium and Settlement at Aylesford, Kent. On March 1st, 1927, there were 142 patients in the sanatorium, and nearly 200 passed through the treatment centre in 1926. The report, which contains detailed information about the organization and results of the sixth annual Poppy Day appeal, may be obtained from the British Legion Appeals Department, 26, Eccleston Square, S.W.1.

Post-GRAdUATE courses on diseases of the heart and circuIation will be held in Vienna, from November 28th to December 10th. Further information may be obtained from Dr. A. Kronfeld, Porzellangasse 22, Vienna IX.

THE Scottish Board of Health has issued as separate reprints the chapters in the annual report of the Board for 1926 relating to (a) encephalitis lethargica, (b) ultra-violet ray therapy, and (c) Schick and Dick tests in diphtheria and scarlet fever. The reprints have been issued at the nominal price of 2d. each, or post free, $2 \frac{1}{2}$ d. Copies can be obtained through any bookseller, or direct from H.M. Stationery Office, 120, George Street, Edinburgh. The annual report was noticed in our columns of July 9th and 16th, and August 6th.

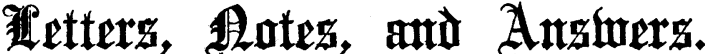

All communications in regard to editorial business should be addressed to Tho EDITOR, British Medical Journal, Brit/sh medical Association House, Tavistock Square, W.C.t.

ORIGINAL ARTICLES and LETTERS forwarded for publication are understood to be offered to the BRITISH MEDICAL JourNil alone unless the contrary be stated. Correspondents who wish notice to be taken of their communications should authenticate notice to be taken of their communications should a
them with their names, not nęcessarily for publication.

Authors desiring REPRINTS of their articles published in the British Medicar Journal rnust communicate with the Financial Secretary and Business Manager, British Medical Association House, Tavistock Square, W.C.1, on receipt of proofs.

All communications with reference to ADVERTISEMENTS, as well as orders for copies of the Joursal, should be addressed to the Financial Secretary and Business Manager.

The TELEPHONE NUMBERS of the British Medical Association and the British Medical Journal are MUSEUM 9861, 9862, 9869, and 9864 (internal exchange, four lines).

The TELEGRAPHIC ADDRESSES are: EDITOR of the British Medical. Jourarac, Aitiology Westcent,

FINANCIAL SECRETARY AND BUSINESS MANAGER (Advertisements, etc.), Articulate Westcent, London.

MEDICAL SECRETARY, Medisecra Westcent, London.

The address of the Irish Office of the British Medical Association is 16, South Frederick Street, Dublin (telegrams: Baciltus, Dublin telephone: 4737 Dublin), and of the Scottish Office, 6, Drumsheagh Gardens, Fdinburgh (telegrams : Associate, Edinburgh; telephono : 24361 Edinburgh).

\section{QUERIES AND ANBWERS.}

\section{Cancer and Diabetes.}

"C. H. S." asks for experiences of the occurrence of carcinoma or other maliguant disease in patients suffering from diabetes.

\section{Petrit mal.}

" CoUrrry G.P." asks for references to recent literature regarding petit mal, and especially as to possible causation by toxic
conditions.

INCOME TAX.

Liability of Colonial Medical Ofjicer.

IJ. J. B. E." is in the Colonial Service and visits the United Kingdom at intervals of from two to two and a half years, but never stays here six morths in any one finaucial year. He has recently acquired the house in which his parents reside and would like to know to what end are directed some questions which he has received from the authorities as to his liability to income tax as a resident in this conntry.

* * Residence is a difficult question, which it is impossible to deal with adequately in a brief answer. The points on which the authorities are seeking information appear to be those which might establish that " J. J. B. E.'s" ownership of the house and the financial arrangaments between himself and his parents are such that he has a place of abode in the United Kingdom to which he returns periodically to an extent sufficient to justify the inference that it is one of his places of residence. If that inference is correct then he would be liable to British income tax on that part of his earnings which he receives in this country.

Loss Due to Coal Strike.

"L. R." has been assessed for many years in respect of the earnings of a colliery practice. For the year to April, 1927, he has been assessed on the usual basis of the three previous years, but owing to the strike his expenses exceeded his gross earnings by £75. The inspector of taxes agreed to the deduction of the loss of $£ 75$ from the 1926-27 assessment, but says that otherwise it must stand.

*** That is in accordance with the law, which does not provide for an adjustment of the aspessment in such circumstances unless the "average" period or part of it was during a predecessor's tenure of the practice. In fact, but for the change in the basis of assessment from the three years' average to the previous year, "L. R." would have been chargeable for 1927-28 on from $£ 1,300$ to $£ 1,400$. If " $L$. R.'s " earnings return to the former level he will not suffer loss in the long run, though obviously for the time being he has to bear the hardship of finding tax to meet a charge quite out of accord with his earnings for the actual year.

\section{Arrears of Liability.}

"J. C. G." pajd tax in 1921, but has received no essessment since. How far back can the authorities now go, and can he claim an allowance for his housekeeper.

* * Assessments can now be made for the year commencing April 5th, 1921, and subsequent years. The housekeeper allowance can be claimed only in the special circumstances, looking after children, etc., set out in the notes accompanying the forms of return.

\section{LETTERS, NOTES, ETC.}

Menstrual " UNCleanlmness."

DR. RoBerT HUTCHISON (London, W.) writes: I am grateful to your correspondents who have replied to the inquiry I made under the above heading. I have also received many private letters on the subject from doctors all over the country which show that the "superstition" referred to is very widespread amongt all classes, - and there seems to be no doubt that it has its origin in a " taboo" which dates back long before Biblical times. Several correspondents have directed my attention to the paper by Macht and Lubin, to which Dr. Feldman refers, and which describes the results of the only attempt I have heard of to investigate the subject on scientific lines. I have not yet had time to study the paper myself, but I confess that it would require very strong evidence to convince me that the tonch of a menstruating woman can excite decomposition in touch of one for investigation by some of the women members of our real enough to lead to a great daal of practical inconvenience.

\section{Binocular fision.}

DR. KENNETH R. SMITH, whose book on Binocular Vision was revied in our issue of September 24th (p. 552), writes to explain reviewed "exerciser for squint" is not intended to be used only that his exiding matter. He prefers an ordinary pack of cands, with reading matter. He prefers an ordinary pack of cands, the centre card with both eres, the card on the left with one eye and the one on the right with the other eye. He prefers playing cards to reading matter or pictures.

\section{Ministry OF Hrateh RFPORT ON SOARLET FeVER. A Correction.}

Dr. Allan C. Parsons, Ministry of Health, writes: I have to thank Dr. J. A. Milne for drawiug attention to an error on page 9 of the recently isoned report of the Ministry of Health on sarrlet fever. Garbolic lotion 10 per cent. is there referred to, instead of cerbolic oil, as it should have been written and is instead of carbolic oil, as it should have been written and is written on other pages which described the technigne of the
Milne treatment, as introduced by his father, the late Dr. Rabart Milne.

\section{A Dischamier.}

DR. A. J. D. Cambron (Northampton) wishes to dissociate himsell from any responsibility for an article in the Westminster Garette of October 14th, headed " Rejuvenation by Fasting," in which his name was mentioned.

\section{VaCancres.}

NOTIFICATIONS of offces vacsint in universities, madical colleges, and of vacsnt resident and other appointments at hospitals, will be found at pages $35,36,37,40$, and 41 of our advertsamen columns, and advertisements as to partnerships, assistantships, A short summary of racant postis notified in the advertivement columns appears in the Supplenont at page 199. 